Vol. 2 Issue 2, Feb.2012, pp.203-206

\title{
SIMULATION AND ANALYSIS OF SOFT-SWITCHING CCM BOOST CONVERTER WITH HIGH POWER APPLICATIONS
}

\author{
C.Benin \\ P.G Scholar, Jeppiaar Engineering College, Chennai, Tamilnadu, India. \\ Dr.M.Sasikumar \\ Professor, Jeppiaar Engineering College,Chennai, Tamilnadu, India.
}

\begin{abstract}
This paper proposes a new soft-switched continuous conduction-mode (CCM) boost converter suitable for high-power applications such as power factor correction, hybrid electric vehicles, and fuel cell power conversion systems. The proposed converter achieves zero-voltage switched (ZVS) turn-on of active switches in CCM and zero-current switched turn-off of diodes leading to negligible reverse-recovery loss. The components voltage ratings and energy volumes of passive components of the proposed converter are greatly reduced compared to the conventional zerovoltage transition converter. Voltage conversion ratio is almost doubled compared to the conventional boost converter. DC/DC converters are often used to provide a DC regulated output voltage. CCM boost converters are increasingly needed in high-power applications. . The major concerns are High power density and High efficiency in high power application. Extension of the proposed concept to realize multiphase $d c-d c$ converters is discussed.
\end{abstract}

KEYWORDS: continuous conduction mode (CCM), Electro Magnetic interference (EMI), Zero Voltage Switching (ZVS), quasi-resonant converter $(Q R C)$,quasi-square-wave converter (QSW), Zero Voltage Transition (ZVT), zero current switched (ZCS),

\section{INTRODUCTION}

The continuous conduction mode (CCM) boost converters have been widely used as the front-end converter for active input current shaping. In recent years, CCM boost converters are increasingly needed in high power applications such as hybrid electric vehicles and fuel cell power conversion systems. High power density and high efficiency are major concerns in high power CCM boost converters. The hard-switched CCM boost converter suffers from severe diode reverserecovery problem in high-current highpower applications. That is, when the main switch is turned on, a shoot through of the output capacitor to ground due to the diode_reverse recovery causes a large current spike through the diode and main switch. This not only incurs significant turn-off loss of the diode and turn-on loss of the main switch, but also causes severe electromagnetic interference (EMI) emission. The effects of the reverse-recovery-related problems become more significant for high switching frequency at high power level. Therefore, the hard-switched CCM boost converter is not capable to achieve high efficiency and high power density at high power level. Many soft-switching techniques on CCM boost converters have been proposed. The zerovoltage switched (ZVS) quasi-resonant converter (QRC) achieves soft switching of the main switch with ZVS and the diode with zero current switched (ZCS) [3], but both main switch and diode suffer from an excessive voltage stress due to resonant operation [1]. The ZVS quasi-square-wave converter (QSW) technique offers ZVS turn-on for both main switch and diode without increasing their voltage stresses. However, both main switch and diode suffer from a high current stress resulting in significant conduction losses. Furthermore, turn-off loss of the main switch is considerable [2].

\section{SOFT SWITCHED CCM BOOST CONVERTER}
A. ZERO VOLTAGE
TRANSITION CONVERTERS
Zero Voltage Transition (ZVT) converters were proposed. In ZVT converters there is an auxiliary resonant circuit across the main switch. The auxiliary circuit is activated only during. The main switch transitions and it is on for only a small time during the switching cycle. Therefore resonance occurs only during the switch transitions. This limits the auxiliary circuit losses [4]. As the resonant inductor slows down the rate of fall of current through the boost diode, the EMI of the ZVT boost converter is also low. Although highest efficiency of the rectifier is achieved using the ZVT boost converter, some common disadvantages of this class of converter are: 


\section{C.Benin, Dr.M.Sasikumar / IOSR Journal of Engineering (IOSRJEN) www.iosrjen.org \\ ISSN : 2250-3021}

Vol. 2 Issue 2, Feb.2012, pp.203-206

1) The circuit suffers from high stress in across the auxiliary switch.

2) The converter in suffers from higher conduction loss due to high RMS currents in auxiliary circuit and the boost diode.

3) The converter suffers from parasitic resonance between the resonant inductor and parasitic capacitance of the auxiliary switch. The saturable inductor limits the switching frequency.

The converter proposed and overcomes all the above problems at the cost of slightly greater voltage stress across the auxiliary switch. However it makes use of an auxiliary transformer to feed-forward some of the energy of the auxiliary circuit to the output.

\section{PROPOSED SOFT SWITCH}

\section{A. MODELLING OF SOFT-SWITCHED (CCM) BOOST CONVERTER}

Fig 1.1 shows the circuit diagram of the proposed CCM boost converter, Upper switch S2 in the proposed converter replaces the rectifier diode in the conventional boost converter. Lower switch S1 and upper switch S2 are operated with asymmetrical complementary switching to regulate the output voltage as shown in Fig4.2. An auxiliary circuit that consists of a capacitor $\mathrm{C} 1$ an inductor L2, two diodes D1 and D2, and a capacitor $\mathrm{C} 2$ is connected on top of the output capacitor $\mathrm{C} 3$ to form the output voltage of the converter.

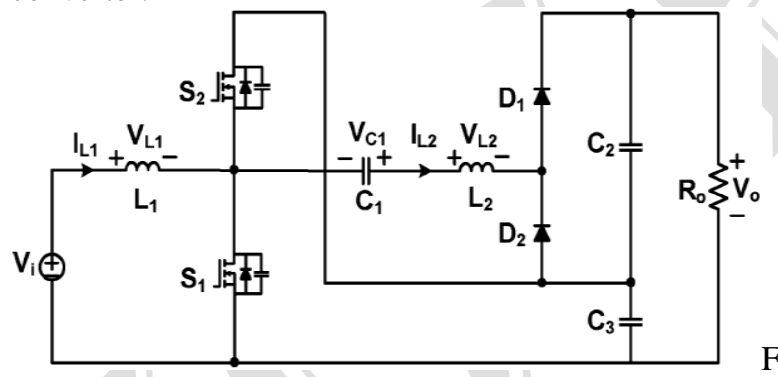
$\mathrm{Fi}$

g 1.1 Proposed soft-switched CCM boost converter.

The auxiliary circuit not only increases the output voltage, but also helps ZVS turn-on of active switches $\mathrm{S} 1$ and $\mathrm{S} 2$ in CCM.

\section{OPERATION MODES OF PROPOSED CONVERTER}

Mode 1: This mode begins when iL2 decreases to zero and D2 is turned on as shown in Fig 1.2. During this mode, the lower switch S1 maintains ON state. Both input inductor current iL1 and auxiliary inductor current iL2 flows through lower switch S1.

$$
\begin{gathered}
\mathrm{diL}_{1} / \mathrm{dt}=\mathrm{v}_{\mathrm{i}} / \mathrm{L}_{1} \\
\mathrm{diL}_{2} / \mathrm{dt}=\left(\mathrm{Vc}_{1}-\mathrm{VC}_{3}\right) / \mathrm{L}_{2}
\end{gathered}
$$

Mode 2: This mode begins when S1 is turned off and the body diode of $\mathrm{S} 2$ is turned on. The gating signal for $\mathrm{S} 2$ is applied during this mode, and S2 is turned on under ZVS conditions. Both iL1 and iL2 are decreasing.

$$
\begin{aligned}
& \mathrm{diL}_{1} / \mathrm{dt}=\left(\mathrm{V}_{\mathrm{i}}-\mathrm{Vc}_{3}\right) / \mathrm{L}_{1} \\
& \mathrm{diL}_{2} / \mathrm{dt}=\mathrm{Vc}_{1} / \mathrm{L}_{2} .
\end{aligned}
$$

At the end of this mode, inductor current iL2 changes its direction of flow and D1 starts to conduct. It should be noted that D2 is turned off under ZCS.

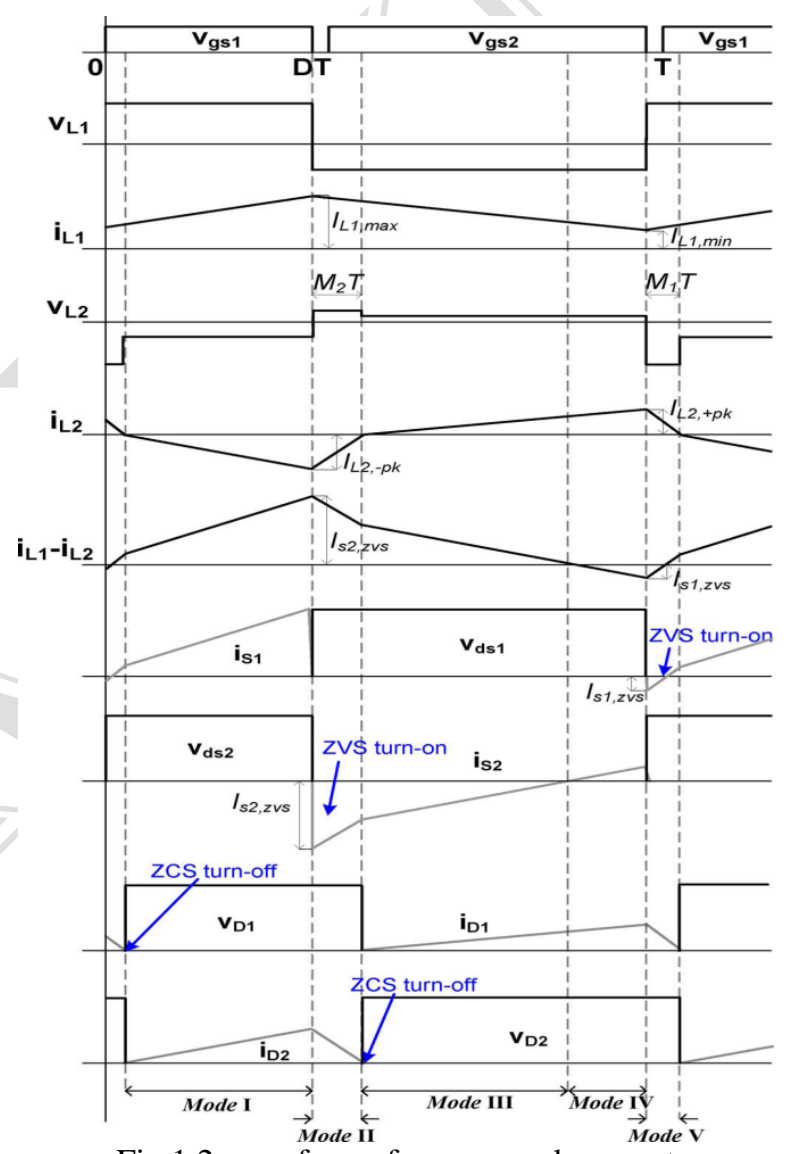

Fig 1.2 waveforms for proposed converter

Mode3: During this mode, iL1 keeps decreasing with the slope determined in Mode II, and iL2 increases. At the end of this mode, switch current iS2 reverses its direction of flow and conducts the main channel of S2.

$$
\mathrm{diL}_{2} / \mathrm{dt}=\left(\mathrm{Vc}_{1}-\mathrm{Vc}_{2}\right) / \mathrm{L}_{2}
$$

Mode4: During this mode, iL1 and iL2 keep flowing with the same slope determined in Mode 3.

Mode5: This mode begins when S2 is turned off and the body diode of S1 is turned on. The gating signal for 


\section{C.Benin, Dr.M.Sasikumar / IOSR Journal of Engineering (IOSRJEN)}

www.iosrjen.org

ISSN : 2250-3021

Vol. 2 Issue 2, Feb.2012, pp.203-206

$\mathrm{S} 1$ is applied during this mode, and $\mathrm{S} 1$ could be turned on under ZVS conditions.

$$
\begin{aligned}
\mathrm{diL}_{1} / \mathrm{dt} & =\mathrm{V}_{\mathrm{i}} / \mathrm{L}_{1} \\
\mathrm{diL}_{2} / \mathrm{dt} & =\left(\mathrm{Vc}_{1}-\mathrm{Vc}_{2}-\mathrm{Vc}_{3}\right) / \mathrm{L}_{2} .
\end{aligned}
$$

Inductor currents iL1 and iL2 start to increase and decrease

\section{VOLTAGE CONVERSION RATIO.}

To obtain the voltage gain of the proposed converter, it is assumed that the voltage across $\mathrm{C} 1, \mathrm{C} 2$, and $\mathrm{C} 3$ are constant during the switching period of TS. The output voltage is given by

$$
\begin{gathered}
\mathrm{Vo}=\mathrm{VC} 2+\mathrm{VC} 3 \\
\text { Or } \\
\mathrm{V}_{\mathrm{o}}=\left(2 /\left(1-\mathrm{D}_{\text {eff }}\right)\right) \mathrm{V}_{\mathrm{i}}
\end{gathered}
$$

Where the effective duty $D_{\text {eff }}$ is defined by

$$
\mathrm{D}_{\mathrm{eff}}=\mathrm{D}+\mathrm{M}_{1}-\mathrm{M}_{2}
$$

The output voltage can also be expressed as

$$
\mathrm{Vo}_{\mathrm{o}}=((2 / 1-\mathrm{D})(\mathrm{Vi}-\Delta \mathrm{V}))
$$

Where $\Delta \mathrm{V}$ is the voltage drop caused by the duty loss $\left(\mathrm{M}_{2}-\mathrm{M}_{1}\right)$. From (9)-(11), the voltage drop $\Delta \mathrm{V}$ can be obtained by

$\Delta \mathrm{V}=\left(\left(2 \mathrm{~V}_{\mathrm{i}}\left(\mathrm{M}_{2}-\mathrm{M}_{1}\right)\right) /\left((1-\mathrm{D})\left(1-\mathrm{D}+\mathrm{M}_{2}-\mathrm{M}\right.\right.\right.$

According to volt-sec balance principle on $\mathrm{L} 2$, capacitor voltage $\mathrm{VC}_{1}$ can be obtained by

$$
\mathrm{VC}_{1}=\mathrm{VC}_{2}\left(1-\mathrm{D}-\left(\mathrm{M}_{2}-\mathrm{M}_{1}\right)\right)+\mathrm{DV}
$$

Where $\mathrm{VC}_{2}$ and $\mathrm{VC}_{3}$ can be expressed as

$$
\begin{array}{r}
\mathrm{VC}_{3}=(1 /(1-\mathrm{D})) \mathrm{V}_{\mathrm{i}} \\
\mathrm{VC}_{2}=\left((1 /(1-\mathrm{D}))\left(\mathrm{V}_{\mathrm{i}}-\Delta \mathrm{V}\right) .\right.
\end{array}
$$

In the steady state, the average output load current equals the average current of D1 and D2 since the average value of the current through L2 (C2) is zero. The following equations can be derived:

$\mathrm{ID}_{1}, \mathrm{av}=\mathrm{Vo} / \mathrm{Ro}=1 / 2(1-\mathrm{D}-(\mathrm{M} 2-\mathrm{M} 1)) \mathrm{IL}_{2},+\mathrm{pk}$

$$
\mathrm{ID} 2, \mathrm{av}=\mathrm{Vo} / \mathrm{Ro}=1 / 2(\mathrm{D}+\mathrm{M} 2-\mathrm{M} 1) \mathrm{IL} 2,-\mathrm{pk}
$$

Where IL2,+pk and IL2,-pk are positive and negative peak values of the inductor current IL2, and are given by (see Fig. 2)

$$
\begin{gathered}
\mathrm{IL}_{2},+\mathrm{pk}=\left(\mathrm{VC}_{1}-\mathrm{VC}_{2}-\mathrm{VC}_{3}\right) \mathrm{M} 1 \mathrm{TS} / \mathrm{L}_{2} \\
\mathrm{IL}_{2},-\mathrm{pk}=\mathrm{VC}_{1} \mathrm{M} 2 \mathrm{TS} / \mathrm{L}_{2} .
\end{gathered}
$$

Diode current $\mathrm{ID}_{2}$, which is a negative portion of current $\mathrm{IL}_{2}$, becomes incremental current in conduction loss.

\section{RESULTS AND DISCUSSION}

\section{A. SIMILUATION FOR SOFT-SWITCHING CCM BOOST CONVERTER IN MOTOR LOAD}

MATLAB simulation of proposed soft switching CCM boost converter with motor load is shown below.

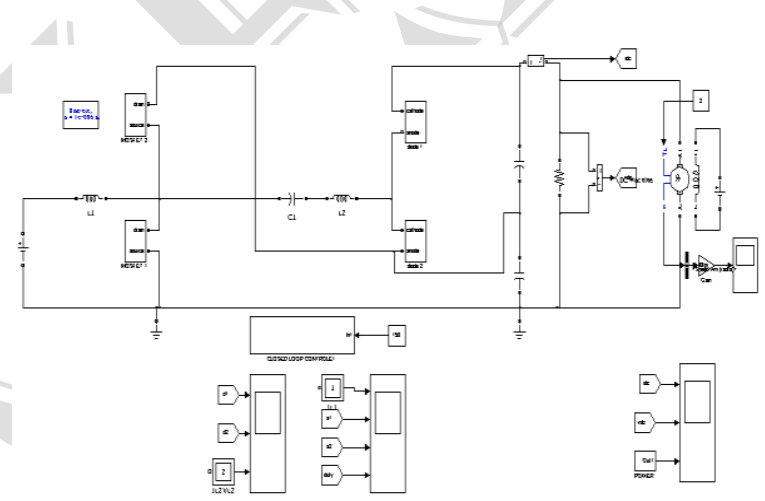

Simulation of soft-switching CCM boost converter with motor load
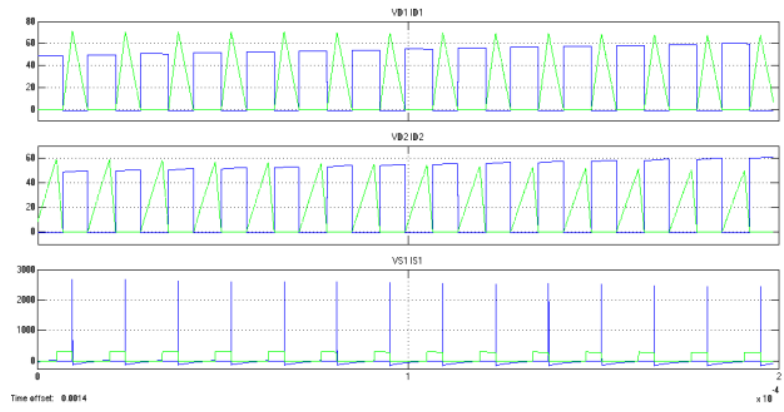

a)

utput voltage and output current for diode $1 \mathrm{~b}$ ) output voltage and output current for diode 2 c) output voltage and output current for MOSFET. 


\section{C.Benin, Dr.M.Sasikumar / IOSR Journal of Engineering (IOSRJEN) www.iosrjen.org \\ ISSN : 2250-3021}

Vol. 2 Issue 2, Feb.2012, pp.203-206

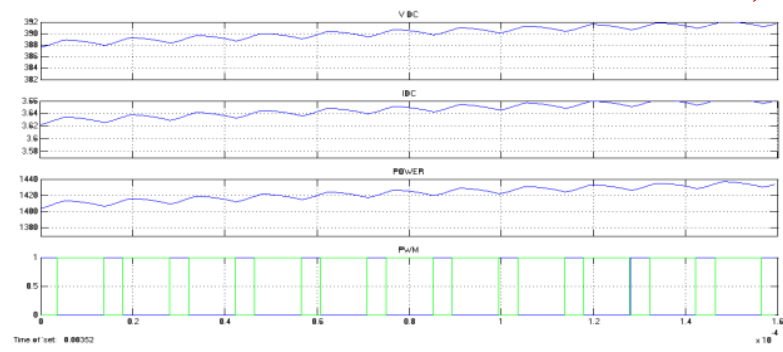

a) output voltage b) output

c) output power d) PWM signal

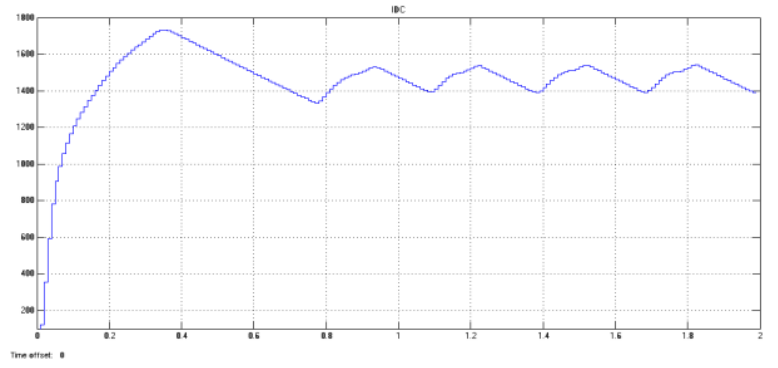

Motor speed by PI controller.

By using the motor load in soft-switching CCM boost converter it achieve rated voltage and run on the rated RPM. It control by PI controller in closed loop and getting high output power and high efficiency

\section{CONCLUSION}

In this paper, a new soft-switched CCM boost converter suitable for high-voltage and high-power application has been proposed. The proposed converter has the following advantages:

1) ZVS turn-on of the active switches in CCM.

2) Negligible diode reverse- recovery due to ZCS turn-off of the diodes.

3) Voltage conversion ratio is almost doubled compared to the conventional boost converter.

4) Greatly reduced components' voltage ratings and energy volumes of most passive- components.

Extension of the proposed concept to realize multiphase $\mathrm{dc}-\mathrm{dc}$ converters for higher voltage and higher power applications has been explored. Experimental waveforms from a $1.5-\mathrm{Kw}$ prototype have been provided and peak efficiency of $97 \%$ was measured at $1200 \mathrm{~W}$.

\section{REFERNCE}

1) K. Liu, R. Oruganti, and F. C. Lee, "Resonant switched-topologies and characteristics," IEEE Trans. Power Electron., vol. PE-2, no. 1, pp. 6274, Jan. 1987.
2) V.Vorperian, Quasi-square-wave converters: Topologies and analysis, "IEEE Trans. Power Electron., vol. 3, no. 2, pp. 183-191, Apr. 1988.

3) G. Hua, E. X. Yang, Y. Jiang, and F. C. Lee, "Novel zero-current-transition PWM converters," IEEE Trans. Power Electron., vol. no. 6, pp. 601606, Nov. 1994.

4) A. Ostadi, X. Gao, and G. Moschopoulos, "Circuit properties od zerovoltage-transition PWM converters," J. Power Electron., vol. 8, no. 1, pp. 35-50, Jan. 2008.

5) E. Ismail and A. Sebzali, "A new class of quasisquare wave resonant converters with ZCS," in Proc. IEEE APEC, 1997, pp. 1381-1387.

\section{ACKNOWLEDGEMENT}

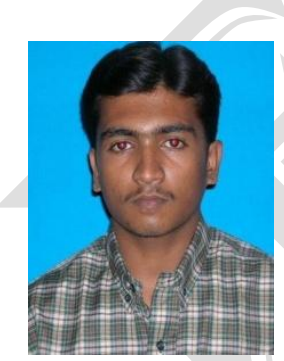

Benin C. is currently pursuing the M.E Degree from Jeppiaar Engineering College, Anna University, Chennai, India. $\mathrm{He}$ received his B.E degree in Electrical and Electronics Engineering in 2009 from Francis xaviour engg college, Anna University, Chennai in 2009. His current research interests include design and implementation of soft switching $\mathrm{ccm}$ boost converter with high power applications.

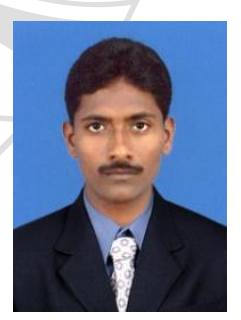

Dr.M.Sasikumar was born in tamilnadu, India on June 17, 1977. $\mathrm{He}$ received the B.E degree in electrical and electronics engineering from K.S.Rangasamy College of Technology,Madras University, India in 1999, and the M.Tech degree in power electronics from VIT University, in 2006. He has obtained his Ph.d. degree from Sathyabama University, Chennai, tamilnadu, India. Currently, he is working as a Professor in Jeppiaar Engineering College, Anna University, Chennai. He has published over 30 technical papers in National and International Conferences /proceedings / journals. 